Snežana Stanković1, Dušan Popović2, Ana Kocić ', Goran Poparić²

${ }^{1}$ University of Belgrade, Faculty of Technology and Metallurgy, Textile Engineering Department, Karnegijeva 4, 11120 Belgrade, Serbia

2University of Belgrade, Faculty of Physics, Studentski trg 12, P.O.Box 368, 11000 Belgrade, Serbia

\title{
Ultraviolet Protection Factor of Hemp/Filament Hybrid Yarn Knitted Fabrics
}

\author{
Ultravijolični zaščitni faktor pletiv, izdelanih iz konopljeno- \\ filamentne hibridne preje
}

\author{
Original Scientific Article/Izvirni znanstveni članek
}

Received/Prispelo 01-2017. Accepted/Sprejeto 03-2017

\begin{abstract}
It is generally accepted that synthetic fibres provide high UV protection capability of textile products, while cellulose fibres have low UV absorption capacity. However, textile materials made of synthetic fibres are not considered to be comfortable for wear in warm weather, whereas cellulose-based textile materials are considered to be much more comfortable to wear, especially in the summer months. For this research, the idea was to produce specially blended knitted fabrics from staple/filament hybrid yarns in order to provide clothing materials with effective UV protection properties, keeping satisfactory comfort properties as well. To obtain hybrid yarns, folding technique was used. The Ultraviolet Protection Factor (UPF), as a quantitative measure of the effectiveness of the material to protect human skin against UV radiation, was determined for the rib knitted fabrics by in vitro test method according to the European standard. The physical properties of the knitted fabrics related to their UV protection properties: bulk density, porosity and air permeability were also determined. The hybrid yarns, from which the rib knitted fabrics were produced, having always hemp yarn as a staple component, caused the differences in UV protection capability of the rib knitted fabrics through the influence of a filament spun component. The hybrid yarn aggregation within knitted fabrics also influenced their UPF values. Even though the pure hemp knitted fabric was marked as "UPF $>50$ " (according to European standard) due to natural pigments and lignin in hemp fibres which act as UV absorbers, most of the hemp/filament hybrid yarn knitted fabrics exhibited even higher UPF. Therefore, the engineering approach proposed in this research was confirmed as an effective way to design clothing materials with optimal UV protection capability and other wear comfort parameters.

Keywords: ultraviolet protection factor, hemp/filament hybrid yarn, knitted fabric, air permeability
\end{abstract}

\section{Izvleček}

Splošno znano dejstvo je, da sintetična vlakna zagotavljajo visoko zaščito pred UV žarki, medtem ko celulozna vlakna UV žarke slabše absorbirajo. Res pa je, da tekstilni materiali, izdelani iz sintetičnih vlaken, niso preveč udobni za nošenje v toplem vremenu, medtem ko so tekstilni materiali na bazi celuloze mnogo bolj udobni za nošenje, zlasti v poletnih mesecih. $V$ naši raziskavi smo želeli izdelati pletiva z mešanjem prediva in filamentnih prej, iz katerih bi lahko izdelovali oblačila, ki bi zagotavljala učinkovito UV zaščito in bila hkrati udobna za nošenje. Za izdelavo hibridnih prej smo uporabili tehniko vitja. Ultravijolični zaščitni faktor (UZF), ki se uporablja kot merilo za učinkovitost materiala pri zaščiti človeške kože pred ultravijoličnimi žarki, smo določili na rebrastem pletivu s testiranjem in vitro v skladu z evropskim standardom. Določili smo tudi fizikalne lastnosti pletiv, ki so povezane z njihovo sposobnostjo UV zaščite: volumsko gostoto, poroznost in zračno prepustnost. Hibridne preje, iz katerih smo izdelali rebrasta pletiva, ki so vedno imele konopljino prejo kot predivno komponento, so povzročile razlike v sposobnosti UV

Corresponding Author/Korespondenčna avtorica:

Assoc Prof DSc Snežana Stanković

Phone: +381 113303857

E-mail: stankovic@tmf.bg.ac.rs
Tekstilec, 2017, 60(1), 49-57

DOI: 10.14502/Tekstilec2017.60.49-57 
zaščite rebrastih pletiv zaradi vpliva filamentne komponente. Na vrednosti UZF je vplivala tudi združitev hibridne preje v pletivu. Četudi je pletivo iz čiste konoplje uvrščeno v kategorijo materialov z "UZF>50" (v skladu z evropskim standardom) zaradi naravnih pigmentov in lignina v konopljinih vlaknih, ki absorbirajo UV žarke, pa je imela večina izdelanih pletiv iz hibridnih prej s kombiniranjem konopljine in filamentne preje celo višji UZF. Naš pristop, predlagan v tej raziskavi, se je torej izkazal kot učinkovit način za načrtovanje oblačilnih materialov z optimalno UV zaščito in drugimi parametri udobja pri nošenju.

Ključne besede: ultravijolični zaščitni faktor, konopljeno-filamentna hibridna preja, pletivo, zračna prepustnost

\section{Introduction}

In the past few decades, sun protection campaigns have been initiated in Australia, the United States and Europe to educate the population about sensible behaviour of the sun, since the rising incidence of skin cancer has been observed for many years. In addition, the decrease of the age at which first symptoms appear is frightening [1]. Because of the long interval between the sun exposure and the development of skin cancer, a higher increase may be expected in the future. Therefore, adequate sun protection is becoming even more necessary. The World Health Organization (WHO) mainly recommends photoprotection by means of clothing for children. Although the textile fabrics themselves undergo limited UV-induced degradation, they still provide excellent UV protection [2].

Various investigations have pointed out the influence of clothing design [3, 4], fabric construction (open porosity, weight, and thickness) [5-13], dyes, chemical agents or UV stabilizers applied to the fabric [10, 14-18], and type of fibre [19-21] on UV protection properties. However, the porosity or tightness of the fabric is the dominant parameter in obtaining UV radiation protection, followed by the ability of fibres to absorb UV radiation (UVR). Nowadays there are some eco-friendly but expensive and complex methods for imparting UV protection capabilities to textile materials. However, in practical view, these technologies are time-consuming, complicated and expensive. In this research, an attempt was made to approach the UV protection properties of knitted fabrics from the viewpoint of the interaction of fibre, yarn and fabric in order to obtain high and permanent UV protection properties.

Growing demand for comfort clothing and environmentally friendly fibres caused the increase in production and use of natural fibres. On the other hand, some of desired garment properties, such as high UV protection capability, shape stability, durability and easy care can be easily achieved by using manmade fibres. Natural cellulose fibres (cotton, flax, hemp) have excellent hygienic properties but low UV absorption capacity, except those grey (virgin state) or dark coloured [5, 22]. Having this in mind, the novel blended knitted fabrics were produced from specially designed staple/filament hybrid yarns in order to provide clothing materials with effective UV protection properties, keeping satisfactory comfort properties as well.

\section{Materials and methods}

In this research, folding technique was used to obtain staple/filament hybrid yarns. Eco-friendly non-bleached hemp yarn was chosen to fold with a filament component. This hemp (Cs) yarn with the linear density of 50 tex was combined with viscose (Cv) filament yarn with the linear density of 30 tex, or textured polyamide (PA) filament $\left(\right.$ Tactel $^{\circledR}, \mathrm{Du}$ Pont) with the linear density of 16 tex. The staple hemp component was mainly two-folded (Cs/Cs, $\mathrm{Cs} / \mathrm{Cv}, \mathrm{Cs} / \mathrm{PA}$ ) with one of the filament component, except the three-folded sample composed of the hemp yarn and two ends of the Tactel component $(\mathrm{Cs} / \mathrm{PA} / \mathrm{PA})$ in order to produce complex yarns with similar linear density. To investigate the influence of the unique internal structure of these specially designed staple/filament hybrid yarns on UV protection properties, homogeneous two-folded hemp yarn was also produced. The folding twist intensity of all the hybrid/filament yarns was 310 turns per meter in $\mathrm{S}$ direction. In order to release the yarns from tension, after folding they were subjected to the following treatments: steaming $20 \mathrm{~min}$ at $80{ }^{\circ} \mathrm{C}$ in an autoclave and storage for at least $72 \mathrm{hr}$ in a conditioned room (65\% relative humidity $\pm 2 \%$ and $20{ }^{\circ} \mathrm{C} \pm 2{ }^{\circ} \mathrm{C}$ ). Measured characteristics of the yarns used in this investigation are presented in Table 1. 
Table 1: Characteristics of the yarns

\begin{tabular}{|l|l|c|c|c|}
\hline \multicolumn{1}{|c|}{ Composition } & Designation & $\begin{array}{c}\text { Linear density } \\
{[\mathrm{tex}]}\end{array}$ & $\begin{array}{c}\text { Twist } \\
{\left[\mathrm{m}^{-1}\right]}\end{array}$ & $\begin{array}{c}\text { Twist factor } \\
{\left[\mathrm{tex}^{1 / 2} \mathrm{~cm}^{-1}\right]}\end{array}$ \\
\hline Hemp & $\mathrm{Cs}$ & 47.8 & 370 & 25.6 \\
\hline Viscose & $\mathrm{Cv}$ & 30.9 & 113 & 6.3 \\
\hline Tactel & $\mathrm{PA}$ & 16.4 & - & - \\
\hline Hemp/hemp & $\mathrm{Cs} / \mathrm{Cs}$ & 95.6 & 297 & 29.0 \\
\hline Hemp/viscose & $\mathrm{Cs} / \mathrm{Cv}$ & 81.6 & 308 & 27.8 \\
\hline Hemp/Tactel & $\mathrm{Cs} / \mathrm{PA}$ & 62.8 & 305 & 24.2 \\
\hline Hemp/Tactel/Tactel & $\mathrm{Cs} / \mathrm{PA} / \mathrm{PA}$ & 78.8 & 308 & 27.3 \\
\hline
\end{tabular}

The rib knitted fabrics (1:1) were knitted from these yarns on the V-bed flat machines differing in gauge settings (E 10 and E 12). In this way, two series of knits were produced differing in stitch density, designed as L (lower density) and $\mathrm{H}$ (higher density). The two-folded hemp yarn could not be processed on a 12 gauge machine due to stiffness of the yarn. Therefore, the hemp/hemp rib knitted fabric with higher stitch density was missing from the experimental material. The knit samples were kept without tension on a flat surface in a conditioned room (65\% R.H. $\pm 2 \%$ and $20{ }^{\circ} \mathrm{C} \pm 2{ }^{\circ} \mathrm{C}$ ) for the relaxation before testing. These commercially produced knitted fabrics in their existing state after last commercial treatment were used for all tests. Stitch density and length of loop were determined according to standard procedure ISO 4921: 2000 (Knitting Basic concepts - Vocabulary). Areal density (mass per unit area) of the knitted fabrics was determined according to ISO 3801: 1977 (Textiles - Woven fabrics - Determination of mass per unit length and mass per unit area). Thickness of the knits was measured in accordance with ISO 5084:1996 (Textiles - Determination of thickness of textiles and textile products). Structural properties of the knitted fabrics are presented in Table 2.

The Ultraviolet Protection Factor (UPF), as a quantitative measure of the effectiveness of the material to protect human skin against UV radiation, was determined for the rib knitted fabrics by in vitro test method according to the European standard EN 13758-1:2001+A1:2006 (Textiles - Solar Ultraviolet Protective Properties - Part I: Method of test for apparel fabrics). This method is a widely accepted laboratory-based test method according to which the UV transmission through textile materials is

Table 2: Structural characteristics of the hemp/filament hybrid yarn rib knitted fabrics

\begin{tabular}{|c|c|c|c|c|c|c|c|}
\hline \multirow[b]{2}{*}{ Composition } & \multirow[b]{2}{*}{ Designation } & \multicolumn{3}{|c|}{ Stitch density } & \multirow{2}{*}{$\begin{array}{l}\text { Loop } \\
\text { length } \\
{[\mathrm{mm}]}\end{array}$} & \multirow{2}{*}{$\begin{array}{l}\text { Thickness } \\
{[\mathrm{mm}]}\end{array}$} & \multirow{2}{*}{$\begin{array}{c}\text { Areal } \\
\text { density } \\
{\left[\mathrm{g} \mathrm{m}^{-2}\right]}\end{array}$} \\
\hline & & $\begin{array}{l}\text { Course } \\
{\left[\mathrm{cm}^{-1}\right]}\end{array}$ & $\begin{array}{l}\text { Wale } \\
{\left[\mathrm{cm}^{-1}\right]}\end{array}$ & $\begin{array}{l}\text { Surface } \\
{\left[\mathrm{cm}^{-2}\right]}\end{array}$ & & & \\
\hline Hemp/hemp & $(\mathrm{Cs} / \mathrm{Cs}) \mathrm{L}^{\mathrm{a})}$ & 12.0 & 11.0 & 132 & 6.8 & 1.649 & 429.1 \\
\hline Hemp/viscose & $(\mathrm{Cs} / \mathrm{Cv}) \mathrm{L}^{\mathrm{a})}$ & 12.0 & 11.0 & 132 & 6.9 & 1.430 & 371.6 \\
\hline Hemp/viscose & $\left.(\mathrm{Cs} / \mathrm{Cv}) \mathrm{H}^{\mathrm{b}}\right)$ & 16.0 & 12.0 & 192 & 5.5 & 1.523 & 430.8 \\
\hline Hemp/Tactel & $(\mathrm{Cs} / \mathrm{PA}) \mathrm{L}^{\mathrm{a})}$ & 12.0 & 11.0 & 132 & 6.6 & 1.218 & 273.6 \\
\hline Hemp/Tactel & $(\mathrm{Cs} / \mathrm{PA}) \mathrm{H}^{\mathrm{b})}$ & 16.0 & 12.0 & 192 & 5.2 & 1.397 & 316.5 \\
\hline $\begin{array}{l}\text { Hemp/Tactel/ } \\
\text { Tactel }\end{array}$ & $(\mathrm{Cs} / \mathrm{PA} / \mathrm{PA}) \mathrm{L}^{\mathrm{a})}$ & 13.2 & 10.0 & 132 & 6.8 & 1.382 & 351.1 \\
\hline $\begin{array}{l}\text { Hemp/Tactel/ } \\
\text { Tactel }\end{array}$ & $\left.(\mathrm{Cs} / \mathrm{PA} / \mathrm{PA}) \mathrm{H}^{\mathrm{b}}\right)$ & 18.0 & 12.0 & 216 & 5.5 & 1.486 & 468.1 \\
\hline
\end{tabular}

\footnotetext{
a) L indicates a rib knitted fabric with lower stitch density

b) $\mathrm{H}$ indicates a rib knitted fabric with higher stitch density
} 
spectrophotometrically assessed. A UV/VIS/NIR PerkinElmer Lambda 9 was used. This is a spectrophotometer equipped with an integrating sphere and therefore all direct and diffuse UVR transmitted through a sample can be collected. Spectrophotometry was carried out in the wavelength range of 290-400 nm in $5 \mathrm{~nm}$ steps. Transmission measurements were conducted on four specimens (in wale and course direction) for each knitted fabric in a flat, tensionless state with the face side exposed to the UV source. The UPF calculates as the ratio of the average of the amount of UV radiation emitted by the source to the amount transmitted through a sample of textile materials with an allowance for differing biologic effectiveness of the various wavelengths in UV radiation. This allowance is essential since the biologic activity of shorter wavelength in the UVB spectrum far exceeds the activity in the UVA spectrum. The UPF is calculated by the equation 1 .

$$
U P F=\frac{\sum_{\lambda=290}^{\lambda=400} E(\lambda) \cdot \varepsilon(\lambda) \cdot \Delta \lambda}{\sum_{\lambda=290} E(\lambda) \cdot T(\lambda) \cdot \varepsilon(\lambda) \cdot \Delta \lambda}
$$

where $E(\lambda)\left[\mathrm{Wm}^{-2} \mathrm{~nm}^{-1}\right]$ is spectral irradiation for appropriate solar radiation spectrum, $\varepsilon(\lambda)$ is the spectral weighting function of erythemal action spectra, $T(\lambda)$ is the spectral transmittance through specimen, and $\Delta \lambda[\mathrm{nm}]$ is appropriate wavelength measuring interval.

Physical properties of the knitted fabrics investigated in this study, in order to explain their UV protection capabilities, included: bulk density, porosity and air permeability. Bulk density of the knitted fabrics, $\rho_{k}\left[\mathrm{~g} \mathrm{~cm}^{-3}\right]$, was calculated by dividing their areal density (mass per unit area) by thickness. Porosity of the knitted fabrics, $P[\%]$, defined as the portion of all air spaces in knitted fabrics both between yarns and inside them, was calculated using the equation 2.

$P=100-\frac{\rho_{k}}{\rho_{f}} \cdot 100$

where $\rho_{f}\left[\mathrm{~g} \mathrm{~cm}^{-3}\right]$ is the fibre density.

Air permeability of the knitted fabrics, defined as the volume of air measured in cubic meters passed per minute through a square meter of fabric at a constant pressure $\left[\mathrm{m}^{3} \mathrm{~m}^{-2} \mathrm{~min}^{-1}\right]$, was measured according to standard procedure (ISO 9273:1995, Textiles - Determination of the permeability of fabrics to air). A Textest FX-3300 air permeability tester was used. The air pressure differential between the two surfaces of a sample $\left(20 \mathrm{~cm}^{2}\right.$ test area) was $100 \mathrm{~Pa}$. Five tests per each knitted fabric were conducted.

\section{Results and discussion}

The folding technique provides a complex yarn differing from its components in geometry as a consequence of the changes in fibre orientation. If complex folded yarn is composed of various fibre and yarn types (staple, filament, textured filament), the hybrid structure is expected to take advantage of both the fibre properties and intrinsic characteristics of component yarns. As a result of the linear density and geometry of the complex yarns, both series of the rib knitted fabrics ( $\mathrm{L}$ and $\mathrm{H}$ designed) were characterized by some variations of structural properties (thickness and areal density, Table 2) and physical properties (bulk density and porosity) which are presented in Table 3.

Table 3: Physical properties of the hemp/filament hybrid yarn rib knitted fabrics

\begin{tabular}{|l|c|c|}
\hline Knitted fabrics & $\begin{array}{c}\text { Bulk density } \\
{\left[\mathrm{gcm}^{-3}\right]}\end{array}$ & $\begin{array}{c}\text { Porosity } \\
{[\%]}\end{array}$ \\
\hline$(\mathrm{Cs} / \mathrm{Cs}) \mathrm{L}$ & 0.260 & 82.6 \\
\hline$(\mathrm{Cs} / \mathrm{Cv}) \mathrm{L}$ & 0.260 & 82.2 \\
\hline$(\mathrm{Cs} / \mathrm{Cv}) \mathrm{H}$ & 0.283 & 81.1 \\
\hline$(\mathrm{Cs} / \mathrm{PA}) \mathrm{L}$ & 0.225 & 84.1 \\
\hline$(\mathrm{Cs} / \mathrm{PA}) \mathrm{H}$ & 0.226 & 83.9 \\
\hline$(\mathrm{Cs} / \mathrm{PA} / \mathrm{PA}) \mathrm{L}$ & 0.254 & 81.3 \\
\hline$(\mathrm{Cs} / \mathrm{PA} / \mathrm{PA}) \mathrm{H}$ & 0.315 & 76.8 \\
\hline
\end{tabular}

Generally, rib knitted fabrics have high stitch density structure. However, the rib knitted fabrics made from staple/filament hybrid yarns were characterized by relatively low bulk density and high porosity, despite their relatively high thickness, making them suitable for summer clothing. Bending rigidity of the hemp yarn may account for the exhibited physical properties of the knitted fabrics. Hemp fibres are coarse and do not have much elasticity and subsequently hemp yarn has the increased bending 
stiffness which must have resulted in a decrease of a knitting barrier manifested itself in limited stitch density. During a row formation in a weft knitted fabric, the yarn takes the shape of the Greek latter " $\Omega$ " which requires sufficient elasticity; otherwise the knit cannot be produced on the chosen gauge setting machine. The porosity of the L-designed Cs/ $\mathrm{Cv}$ knitted fabric was similar to that of the pure hemp rib knit, whereas the porosity increased for $\mathrm{Cs} / \mathrm{PA}$ knit and slightly reduced for Cs/PA/PA knit. However, visual examination of the L-designed knitted fabrics indicated some differences in pore distribution between them, as presented in Figure 1 .

As a consequence of increased bending rigidity or reduced flexibility of the hemp yarn, the all-hemp rib knit with higher stitch density could not be produced. However, it seems that the introduction of a filament component into complex yarn caused the improved elasticity of the hybrid structure which made it possible to produce the hemp/filament knitted fabrics with higher stitch density.
The $\mathrm{H}$-designed rib knits made from hybrid yarns, with the exception of hemp/Tactel knit, were characterized by reduced porosity in relation to the corresponding lower stitch density variants (Table 3 ). Visual examination of the H-designed knitted fabrics indicated also the changes in their open porosity, as can be noted in Figure 2. An increase in the surface stitch density of the rib knits led to a reduction in the inter-yarn pore size. This is particularly observed in Cs/PA/PA rib knit where changes in loop configuration noted not only in relation to the L-designed counterpart but also in relation to the other knitted fabrics (Table 2). The changes in loop configuration, manifested in higher course density of the Cs/PA/PA rib knit, can be explained by the improved elasticity of the Cs/PA/PA hybrid yarn.

Since the open porosity of a textile material is a governing factor which influences its transmission behaviour, the air permeability of the rib knitted fabrics was determined as an indication of their

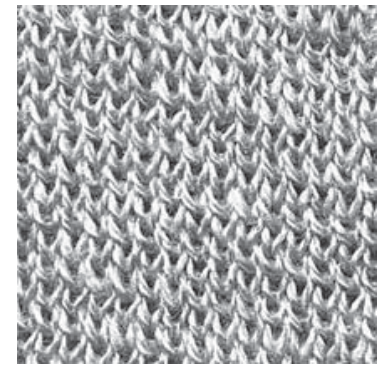

a)

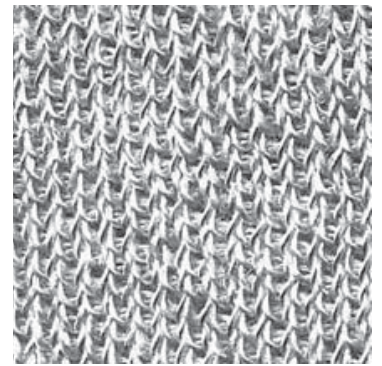

b)

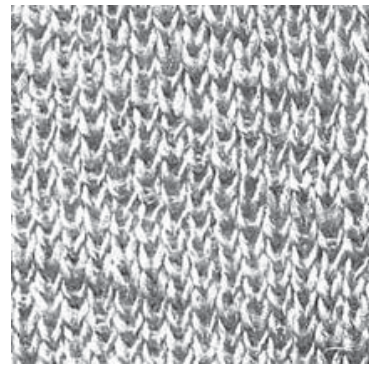

c)

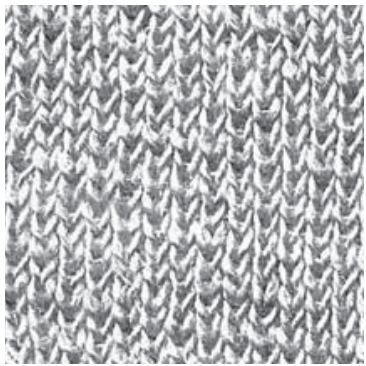

d)

Figure 1: Photographs of the L-designed rib knitted fabrics: (a) hemp/hemp Cs/Cs, (b) hemp/viscose Cs/Cv, (c) hemp/Tactel Cs/PA and (d) hemp/Tactel/Tactel Cs/PA/PA

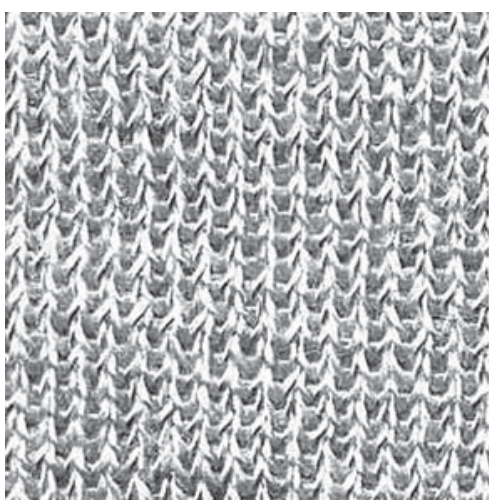

a)

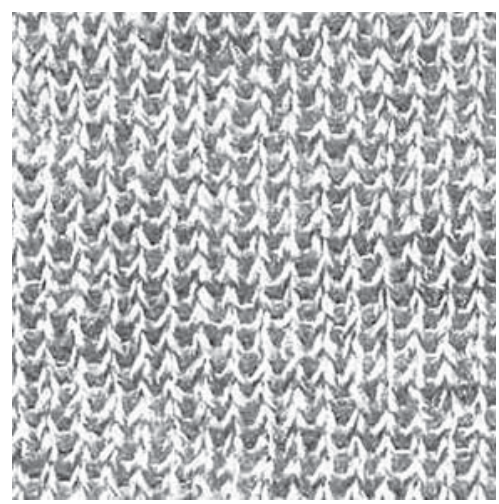

b)

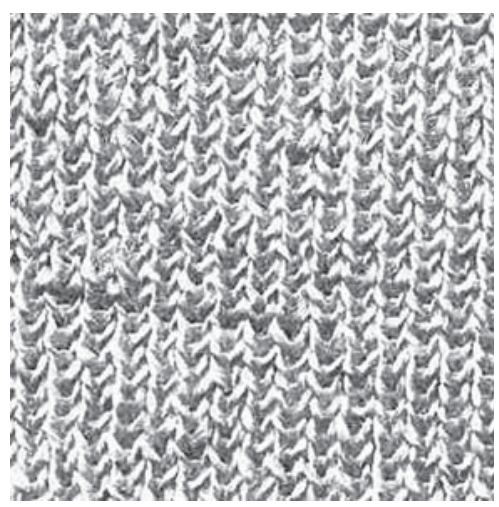

c)

Figure 2: Photographs of the H-designed rib knitted fabrics: (a) hemp/viscose $C s / C v$, (b) hemp/Tactel Cs/PA and (c) hemp/Tactel/Tactel Cs/PA/PA 
open porosity. Air permeability was chosen because of the known fact that the amount of airflow through fabric depends mostly on the openness of the fabric structure. The results of the air permeability of the rib knitted fabrics are given in Figure 3. Within the L-designed rib knitted fabrics, the hemp/viscose knit was most permeable followed by hemp/Tactel, all-hemp and hemp/Tactel/Tactel knits. Since the rib knitted fabrics were characterized by the same stitch density, the spacing of yarn appeared to be the main parameter influencing the openness of fabric structure and hence air permeability. In the case of more compact yarn, the air in the yarn is reduced but the space between yarn segments is larger, so the fabric has a more open, permeable structure. In addition to linear density of the viscose filament which is lower than that of the single hemp yarn, regular cross section, smooth surface and close packing of monofilaments in viscose yarn caused a reduction in hemp/viscose hybrid yarn spacing in relation to that of the twofolded hemp yarn. As a result, Cs/PA knit exhibited increased air permeability. Monofilaments accommodation into a polyamide textured filament caused a high bulk structure with a large content of air space in hemp/Tactel hybrid yarn. Although Cs/ PA knit looks like having quite close structure due to durable crimps and loops introduced into a Tactel component (Figure 1c), its air permeability which was higher than that of all-hemp knitted fabric can be explained by the lowest linear density of Cs/PA yarn and the lowest thickness of the corresponding knit. The Cs/PA/PA knitted fabric was thinner than pure hemp knit but exhibited lower

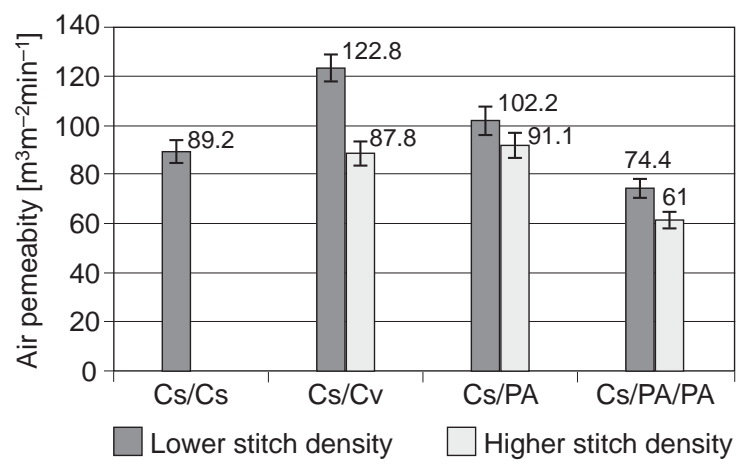

Figure 3: Air permeability of the hemp/filament hybrid yarn knitted fabrics (the coefficient of variation included) fabrics (The coefficient of variation is included.) air permeability due to high covering power or the spacing of the Cs/PA/PA hybrid yarn coming from its configuration. The $\mathrm{H}$-designed hemp/filament knitted fabrics exhibited, as expected, lower air permeability then that of the L-designed counterparts due to the increased stitch density and consequently reduced size of inter-yarn pores. The air permeability of the $\mathrm{H}$-designed $\mathrm{Cs} / \mathrm{Cv}$ and $\mathrm{Cs} / \mathrm{PA}$ knits was similar to that of the pure hemp knit, whereas the Cs/PA/PA knit exhibited even lower air permeability as a consequence of its increased stitch density.

According to the spectrophotometric measurement, given in Table 4, the rib knitted fabrics were characterised by low UVB and UVA transmittance. In comparison with the pure hemp knitted fabric, the hemp/viscose, $(\mathrm{Cs} / \mathrm{Cv}) \mathrm{L}$, knit was characterised by higher transmittance and consequently lower UPF (Figure 4), which can be explained by higher open porosity of knit. UPF values (Figure 4) indicated the excellent protection capability of all other hemp based knitted fabrics (UPF>50) according to European standard (Textiles - Solar UV protective properties - Part 2: Classification and marking of apparel (EN 13758-2:2003+A1:2006). The excellent capability of all-hemp knit to protect against UVR can be attributed to the fact that hemp single yarn was in the gray-state, and thus natural pigments and lignin in hemp fibres could act as UV absorbers having a favourable effect on UV protection.

The introduction of the textured component into hemp/textured filament hybrid yarns caused the reduction in the UVR transmission through the knitted fabrics and hence UV protection increased. On account of durable crimps and loops introduced into the textured polyamide filament, the hemp/textured filament hybrid yarns were characterized by large spacing within the rib knits. The Cs/PA/PA knit having the lowest air permeability and consequently the lowest openness exhibited the lowest UVR transmittance and the highest UPF. However, Cs/PA knit exhibited the UVR transmittance lower than that of the pure hemp knit (Table 4) despite its higher air permeability. Bearing in mind the fact that fabric porosity is a static property unlike air permeability which includes dynamic force (air pressure difference), it seems that in this case the openness - air permeability relation is not simple as expected. On the other hand, by visual examination of the samples, it seems that both Cs/PA and Cs/PA/ 
PA knitted fabrics were characterized by similar open porosity which is lower than that of the pure hemp knit (Figure 1), and thus have a higher UPF. Monofilaments accommodation into Tactel yarn caused a high bulk structure which allowed blocking of UV light passage, but the momentum of air flow apparently spaced them out letting the air pass through. Probably the hemp/Tactel hybrid yarn is more susceptible to the spreading of monofilaments since only one Tactel component was included in the hybrid yarn. Distinctive UV protection capability of Cs/PA/PA knitted fabric might have also resulted from two Tactel filaments containing agents which act as UVR absorbers.

By increasing the stitch density of the hemp/filament hybrid yarn knitted fabrics, the UVR transmission was reduced to a large extent for Cs/Cv knit (for about $85 \%$ ), and slightly for Cs/PA and Cs/PA/ PA knitted fabrics. However, the interesting fact was noted when the all-hemp and $\mathrm{H}$-designed $\mathrm{Cs} / \mathrm{Cv}$ and Cs/PA knits were compared. Even though these knits were characterized by similar air permeability, they exhibited differences in UVR protection capability (Table 4 and Figure 4). This can be explained by considering the interaction between UV radiation and fibres. When UV light reaches a textile fabric, UVR can be transmitted through the pores, and reflected or absorbed by fibres. Fibres can absorb or reflect UVR not only from the surface of the fabric but also from the specific surface of the open pores. It is assumed that the absorption of UVR by fibres inside the channels was hastened with a decrease in the size of open pores in the H-designed knitted fabrics. It may be expected that hemp fibres were responsible for it in Cs/Cv knitted fabric. Since both hemp and textured polyamide filament may have contributed to the increased UVR absorption in Cs/ PA knit, this can be a reason for its highest UV protection capability among the knitted fabrics having similar air permeability.

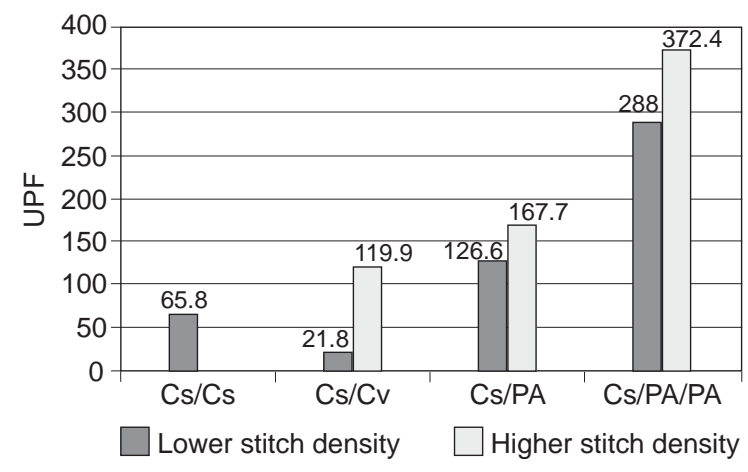

Figure 4: Ultraviolet protection factor of the hemp/filament hybrid yarn knitted fabrics

\section{Conclusion}

In the scope of this study, the rib knitted fabrics composed of hemp/filament hybrid yarns were compared to the pure rib hemp knit in terms of UV radiation transmittance in order to bring to light the potential of the formation of novel hybrid structures for UV protection. The folding technique applied for a combination of staple and filament yarns made it possible not only to combine different fibre properties, but to provide the complex yarn with the unique internal structure. The results confirmed that folding operation could be an effective way to obtain "new quality" textile structures with specific

Table 4: UV protection properties of the hemp/filament hybrid yarn knitted fabrics

\begin{tabular}{|l|c|c|c|}
\hline \multirow{2}{*}{ Knitted fabrics } & \multicolumn{3}{|c|}{ Transmission [\%] } \\
\cline { 2 - 4 } & UVB $\left(\mathrm{SD}^{\mathrm{a})}\right)$ & UVA (SD) & UVR \\
\hline$(\mathrm{Cs} / \mathrm{Cv}) \mathrm{L})$ & $1.47(0.04)$ & $1.45(0.06)$ & 1.46 \\
\hline$(\mathrm{Cs} / \mathrm{Cv}) \mathrm{L}$ & $4.44(1.67)$ & $4.55(1.51)$ & 4.49 \\
\hline$(\mathrm{Cs} / \mathrm{Cv}) \mathrm{H}$ & $0.65(0.1)$ & $0.66(0.1)$ & 0.65 \\
\hline$(\mathrm{Cs} / \mathrm{PA}) \mathrm{L}$ & $0.58(0.11)$ & $0.58(0.11)$ & 0.58 \\
\hline$(\mathrm{Cs} / \mathrm{PA}) \mathrm{H}$ & $0.43(0.14)$ & $0.45(0.14)$ & 0.44 \\
\hline$(\mathrm{Cs} / \mathrm{PA} / \mathrm{PA}) \mathrm{L}$ & $0.23(0.08)$ & $0.24(0.08)$ & 0.24 \\
\hline $\mathrm{Cs} / \mathrm{PA} / \mathrm{PA}) \mathrm{H}$ & $0.19(0.05)$ & $0.20(0.05)$ & 0.20 \\
\hline
\end{tabular}

a) Standard deviation 
properties. In addition, it was proved that blended yarns obtained by combining the staple yarn with other yarn types in complex hybrid yarns could be the way to take advantage of both, the fibre properties and the intrinsic characteristics of plied components (filament, textured). This complex interaction can also be modified by knitted fabric design through the influence on yarn aggregation within fabrics.

Although the pure hemp knitted fabric was placed in the "excellent UV protection category" (according to the Australian/New Zealand standard AS/ NZS 4399) due to natural pigments and lignin in hemp fibres which act as UV absorbers, most of the hemp/filament knitted fabrics exhibited even higher UPF. Therefore, this engineering approach merits further consideration as an effective means for design of clothing materials with optimal UV protection properties and other wear comfort parameters. Although the results obtained cannot be explicitly extrapolated to textile materials other than those tested in this study, it could be said with certainty that the configuration of complex yarn can be a key determinant of the UV protection capability of textile materials.

\section{Acknowledgement}

This research was funded by the Ministry of Education, Science and Technological Development of the Republic of Serbia by the Project OI-171029.

\section{References}

1. ALMAHROOS, Mona, KURBAN, Amal K. Sun protection for children and adolescents. Clinics in Dermatology, 2003, 21(4), 311-314, doi: 10.1016/S0738-081x(03)00044-0.

2. ANDRADY, AL., TORIKAI, A., REDHWI, HH., PANDEY, KK., GIES, Peter. Consequences of stratospheric ozone depletion and climate change on the use of materials. Photochemical \& Photobiological Sciences, 2015, 14(1), 170-184, doi: 10.1039/C4PP90038C.

3. WILSON, Cheryl Anne, PARISI, Alfio V. Protection from solar erythemal ultraviolet radiation simulated wear and laboratory testing. Textile Research Journal, 2006, 76 (3), 216-225, doi: $10.1177 / 0040517506060907$.
4. KHAZOVA, Marina, O'HAGAN, John, GRAINGER K.J-L. Assessment of sun protection for children's summer 2005 clothing collection. Radiation Protection Dosimetry, 2007, 123(3), 288-294, doi: 10.1093/rpd/ncl146.

5. STANKOVIĆ, Snežana B., POPOVIĆ, Dušan, POPARIĆ, Goran B., BIZJAK, Mateja. Ultraviolet protection factors of gray-state plain cotton knitted fabrics. Textile Research Journal, 2009, 79 (11), 1034-1042, doi: 10.1177/0040517508102016.

6. DIMITROVSKI, Krste, SLUGA, Franci, URBAS Raša. Evaluation of the structure of monofilament PET woven fabrics and their UV protection properties. Textile Research Journal, 2010, 80(11), 1027-1037, doi: 10.1177/0040517509352527.

7. DAVIDS, Sandra, CAPJACK, Linda, KERR, Nancy, FEDOSEJEVS, Robert. Clothing as protection from ultraviolet radiation: which fabric is most effective? International Journal of Dermatology, 1997, 36(5), 374-379, doi: 10.1046/j. 1365-4362.1997.00046.x.

8. GRANCARIĆ, Ana Marija, PENAVA, Željko, TARBUK Anita. UV protection of cotton - the influence of weaving structure. Hemijska industrija, 2005, 59 (9-10), 230-234, doi: 10.2298/ HEMIND0510230G.

9. DULĘBA-MAJEK, Malgorzata. Transmission of UV radiation through woven fabrics in dependence on the inter-thread spaces. Fibers \& Textiles in Eastern Europe, 2009, 17 (2), 34-38.

10. MAJUMDAR, Abhijit, KOTHARI, Vijay Kumar, MONDAL, Achitya Kumar, HATUA, Piyali. Effect of weave, structural parameters and ultraviolet absorbers on in vitro protection factor of bleached cotton woven fabrics. Photodermatol. Photoimmunol. Photomed. 2012, 28 (2), 5867, doi: 10.1111/j.1600-0781.2011.00638.x.

11. WONG, Wai-yin, LAM, Jimmy Kwok-Cheong, KAN, Chi-wai, POSTLE, Ron. Influence of knitted fabric construction on the ultraviolet protection factor of greige and blended cotton fabrics. Textile Research Journal, 2013, 83(7), 683-699, doi: 10.1177/0040517512467078.

12. KAN, Chi-wai. A study on ultraviolet protection of $100 \%$ cotton knitted fabrics: effect of fabric parameters. Scientific World Journal, 2014, 2014, ID 506049, doi: 10.1155/2014/506049.

13. KOCIĆ, Ana, POPOVIĆ, Dušan, STANKOVIĆ, Snežana, POPARIĆ, Goran. Influence of yarn folding on UV protection properties of hemp 
knitted fabrics. Hemijska industrija, 2016, 70(3), 319-327, doi: 10.2298/HEMIND141126036K.

14. OSTERWALDER, Uli, SCHLENKER, W., ROHWER, Hauke, MARTIN, E, SCHUH, S. Facts and fiction on ultraviolet protection by clothing. Radiation Protection Dosimetry, 2000, 91 (1-3), 255-259, doi: org/10.1093/oxfordjournals.rpd. a033213.

15. DUBROVSKI DOBNIK, Polona. The influence of color and woven fabric construction on ultraviolet protection factor. In $6^{\text {th }}$ World Textile Conference AUTEX 2006. NC State University, Raleigh, North Carolina, USA, 2006.

16. ABIDI, Noureddine, HEQUET, Eric, TARIMALA, Sowmitri, DAI, Lenore L. Cotton fabric surface modification for improved UV radiation protection using sol-gel process. Journal of Applied Polymer Science, 2007, 104(1), 111-117, doi: 10.1002/app.24572.

17. SARKAR, Ajoy K. On the relationship between fabric processing and ultraviolet radiation transmission. Photodermatology, Photoimmunology \& Photomedicine, 2007, 23 (5), 191-196, doi: 10.1111/j.1600-0781.2007.00306.x.
18. KAN, Chi-wai, AU, CH. Effect of biopolishing and UV absorbers treatment on the UV protection properties of cotton knitted fabrics. Carbohydrate Polymers, 2014, 101, 451-456, doi: 10.1016/j.carbpol.2013.09.044.

19. ROY, Colin R., GIES, Peter H. Protective measures against solar UV exposures. Radiation Protection Dosimetry, 1997, 72(3-4), 231-240, doi: 10.1093/oxfordjournals.rpd.a032095.

20. HOFFMANN, Klaus, KASPAR Katharina, GAMBLICHER, Thilo, ALTMEYER, Peter. In vitro and in vivo determination of the UV protection factor for lightweight cotton and viscose summer fabrics: a preliminary study. Journal of the American Academy of Dermatology, 2000, 43(6), 10091016, doi: 10.1067/mjd.2000.107959.

21. PAVKO ČUDEN, Alenka, URBAS Raša. Impact of elastane addition on UV protective properties of viscose and polyacrylonitrile knits. Acta Chimica Slovenica, 2011, 58(4), 854-859.

22. TARBUK, Anita, GRANCARIĆ, Ana Marija, ŠITUM, Mirna, MARTINIS, Mladen. UV clothing and skin cancer. Collegium Antropologicum, 2010, 34(S2), 179-183. 